\title{
Financial Integration in ASEAN-5
}

\author{
Laura Grace Gabriella, ${ }^{\mathrm{a}, *}$, Revathy Suryanarayana ${ }^{\mathrm{b}}$, Vania Esady ${ }^{\mathrm{c}}$ \\ ${ }^{a}$ Research Fellow, Department of Macroprudential Policy, Bank Indonesia \\ ${ }^{b}$ Research Associate, Indian School of Business, Hyderabad \\ ${ }^{c}$ PhD student, Department of Economics, City, University of London
}

\begin{abstract}
The financial integration in South East Asia has varied over time. This paper focuses on three periods: before, during, and after the global financial crisis in 2008. This paper finds that ASEAN-5 countries have indeed taken a step towards financial integration. While we do not observe any (cointegrating) long-run relationships between the ASEAN-5 countries, we find that there has been a significant increase in the volatility spillovers between them. This is particularly true in the recovery period following the global financial crisis.
\end{abstract}

Keywords: Financial Integration; Global Financial Crisis; ASEAN; GARCH

\begin{abstract}
Abstrak
Integrasi keuangan di Asia Tenggara telah mengalami perubahan dari waktu ke waktu. Penelitian ini berfokus pada tiga periode waktu, yaitu pada sebelum, saat, dan setelah Krisis Keuangan Global tahun 2008. Hasil penelitian ini menemukan bahwa negara ASEAN-5 memiliki kecenderungan kearah integrasi keuangan. Walaupun kami belum melihat adanya hubungan jangka panjang dari kelima negara tersebut, namun kami menemukan adanya peningkatan signifikan dari volatility spillover diantara mereka. Hal ini khususnya benar terjadi sepanjang periode pemulihan dari Krisis Keuangan Global.
\end{abstract}

Kata kunci: Integrasi Keuangan; Krisis Keuangan Global; ASEAN; GARCH

JEL classifications: F21; F33

\section{Introduction}

South East Asia has grown rapidly in the last two decades along with the young population and its consequent higher saving rates. This development boosts the number of middle-income population and the demand for financial services, as financial services have a high income elasticity of demand - likely to be larger than one. The rapid pace of economic growth makes the region's stock markets become attractive to investors from outside the region seeking for new opportunities to diversify their portfolio.

With this background, ASEAN has put a greater emphasis on economic and financial integration.

\footnotetext{
* Corresponding Address: Department of Macroprudential Policy, Bank Indonesia. JIn. MH. Thamrin No. 2, Jakarta 10350. E-mail: lauragrace.manurung@gmail.com.

**E-mail: revathy.s.narayana@gmail.com.

E-mail: vania. esady@gmail.com.
}

The ASEAN Economic Community (AEC) strives for a greater integration among countries within the region. However, there could be potential side effects in terms of financial stability across the region. For emerging economies, such as the Association of South-East Asian Nations (ASEAN), external shocks on the stock market can often trigger comovement across different countries. Our paper empirically analyzes how volatility from one stock market spills over to other ASEAN stock markets.

ASEAN economies as they vary by sizes of market capitalization and quality of financial market infrastructure. Other differences could be seen in their institutional capacity to implement reformation, and the readiness of their financial standards (ADB 2013) as they are at different stages of economic and financial development. However, the five original members of ASEAN - Indonesia, Malaysia, Singapore, Thailand, and Philippines - holds a more similar characteristics and are likely to lead the in- 
tegration. Therefore, this paper focuses on this set of countries, and refers to it as ASEAN-5.

Nevertheless, there has been a tremendous progress towards more integrated financial markets, not only among the countries in the region but also with countries from outside of the region. Almekinders et al. (2015) observes that this integration is mirrored in the increase in direct investment within the region, increased in cross-border banking linkage, and foreign participation in ASEAN capital market. However, if the countries in the region comove more, the benefit from portfolio diversification may not be as great across countries. Nonetheless, portfolio investors could still gain investment in the region by the reduced transaction costs and increase in share liquidity.

A more integrated financial market reaps many benefits, such as more efficient capital allocation as well as risk sharing. For example, greater financial market integration between two countries could inherently reduce financial barriers and international transaction costs. Typically, as the financial barriers in the region are gradually removed, the degree of financial integration would increase in the same way of their trade integration.

This paper investigates the key issue of financial market integration, that is, how has financial integration affected (adverse) volatility spillovers across the different countries' stock markets, in particular around the global financial crisis. Hence, we consider a period from after the Asian financial crisis, from January 1, 1999 to February 2, 2015. In general, among the five stock market returns, we observe a higher correlation during and post-global financial crisis periods compared to the pre-crisis period. To the authors' knowledge, this is the first paper to study the impact of global financial crisis on ASEAN-5 stock market spillovers. The existing literature finds that volatility spillover effect (KalemliOzcan et al. 2010) - has also intensified during a crisis period in other countries (Chakrabarti 2011; Narayan, Sriananthakumar, \& Islam 2014). We seek to establish if this was also true in an emerging but integrated economy like ASEAN. We use a GARCH $(1,1)$ model to focus on the volatility spillovers between countries during the three time periods.

In Section II, we review some of the literature associated with the model we propose to use in our analysis. In the third section, we account for our data and illustrate our methodology. Section IV serves the results and analysis along with policy implication. And section $\mathrm{V}$ concludes.

\section{Literature Review}

We classify the literature into two sections. First, we focus on the literatures that study the movement the correlation and cointegration - of ASEAN financial markets following the Asian and global financial crisis. Second, we explore literatures that apply the appropriate econometrics model to study stock market integration.

\subsection{ASEAN and Financial Crises}

ASEAN was formed as an international community for economic and political cooperation in 1967. ASEAN is strategically placed within the Asian region with immense potential for mutual economic development and financial cooperation. Click \& Plummer (2005) emphasized the financial theory where an integrated regional financial market is more efficient than a segmented national financial market. As AEC pushes towards a more integrated financial market, it is hoped that the stock markets of these countries will move in a similar direction implying high correlation. Stock prices of different countries that share short- and long-run relationships may imply a convergence as well as integration of those stock markets. Consequently, we review the literatures on the ASEAN financial integration, in particular, in terms of long-run cointegration relationships and volatility transmission.

ASEAN economies are among the many countries that were greatly impacted by the Asian financial crisis. There was a growth in the number of studies for stock market integration in Asia. Naturally, due to the primary focus of ASEAN for financial cooperation, a strand of literature considers in particular the integration (or segmentation) of Southeast Asian stock markets caused by the crisis.

Daly (2003) employs correlation and cointegration analysis to describe the behavior of ASEAN-5 stock markets before and after the Asian financial crisis. He finds that correlation increases (hence, higher interdependencies) across the ASEAN-5 countries. However, the overall results suggest there is only 
little evidence on the increase of co-integration between the Southeast Asian stock markets after the crisis.

Similarly, using a time series technique of cointegration, Click \& Plummer (2005) extracts the long-run relation among the ASEAN-5 stock markets. The empirical results suggest that these stock markets are cointegrated only to a certain extend of the economic sense. Therefore, they suggest the stock market integration is far from complete.

A decade following the Asian financial crisis, the world economy was hit by the global financial crisis - originating in the US market and spreading over other countries' financial market. The degree of integration among stock markets tends to change around the periods of financial crises (for example, Wang 2014; Morana \& Beltratti 2008; Huyghebaert $\&$ Wang 2010). There are a number of literatures looking at the effect of the recent crisis on Southeast Asian countries from a different angle. For instance, Guidi \& Gupta (2012) study the asymmetric volatility dynamics in the Southeast Asian stock market. They observe that the global financial crisis has indeed affected the ASEAN-5 stock markets, in terms of capitalisation and turnover.

\subsection{Financial Integration Methodolo- gies}

The conclusions in the literature regarding the integration of Southeast Asian stock markets seem contradictory - that is, no significant evidence of stock market integration. This might be partially attributable to different methodologies and econometrics techniques used in the studies. We consider literatures that study not only cointegration but also volatility transmission, which may demonstrate some degree of stock market integration. In this section the studies are not limited to Southeast Asian economies.

Existing literature examines financial integration in different parts of the world, especially after a financial or a political shock. The majority of volatility transmission studies have focused on established financial and capital markets such as US, China, and Europe. Narayan, Sriananthakumar, \& Islam (2014) investigates the patterns and causes of stock market integration of selected emerging Asian countries against the US, China, and India from 2001 to 2012. They use daily, weekly, and monthly stock data to compare the pattern of integration. Furthermore, they implement ARMA-DCC-GARCH $(1,1)$ to show that correlations between stock markets are time varying and volatile, indicating the dependence of stock markets on exogenous shocks. They argue that the strongest correlation between the stock markets happened during the global financial crisis. They also show that the time-varying bilateral correlation is highly volatile because of the underlying financial conditions.

Contrary to the findings of Narayan, Sriananthakumar, \& Islam (2014), Allen, Amram, \& McAleer (2011) finds sparse evidence of volatility spill over from Chinese stock market to its neighbors and trading partners post the global financial crisis period. They used univariate GARCH, multivariate VARMAGARCH, and multivariate VARMA-AGARCH models to test for constant conditional correlation and volatility spillover effects between China and its trading partners. Another line of literature captures financial integration among unified political regions. For example, Fratzscher (2001) investigated the integration process of European equity markets since 1980s focusing on the role of EMU on the process of the financial integration. He utilized a trivariate GARCH and shows that the European equity markets have become highly integrated only since 1996 . $\mathrm{He}$ also finds that EMU played a significant role for the integration process as the process of monetary unification eliminated the uncertainty of exchange rate volatility. A more recent study by Samkharadze (2009) investigated the financial interdependence between EU members and EU candidate countries using BEKK-GARCH model. They find significant evidence of spillover between these two groups. They also find that the conditional correlations of some candidate countries with old member countries have increased since they joined EU.

Additionally, there is an existing literature on less established markets, and on the relationship between developed and emerging markets. Brooks, Davidson, \& Faff (1997) investigated the applicability of ARCH/GARCH to the volatility of South African stock markets, in the event of an important political change, over the period of 1986 to 1996 . The president's announcement in 1990 - proclaiming that South Africa would undergo a fundamental change in its political structure that will free South Africa from being the subject of political and economic isolation by the international community - was ex- 
pected to transform South Africa's financial markets to become more integrated with the international financial markets. Their results support the applicability of ARCH/GARCH models, which suggest greater international integration of the Johannesburg Stock Exchange in the period of post 1990 announcement.

Moreover, Li, \& Giles (2013) studied the long and short run shock and volatility spillovers across US, Japan, and six Asian emerging countries stock markets over the period of January 1993 to December 2012. They have modeled volatility spillover through asymmetric multivariate GARCH model. Their results show significant unidirectional volatility spillover from US market to Japan and the six Asian emerging countries. The volatility spillover between US and Asian markets is stronger and bidirectional, especially during the Asian financial crisis in 19971998. Meanwhile, the linkages between the Asian and Japanese stock markets become more apparent after the global financial crisis.

As described in the studies above, ARCH, GARCH and different variations of the model are applicable to study the volatility spill over. The scope of this paper is to utilize GARCH $(1,1)$ model to analyze the volatility spill over between two countries in the ASEAN-5 after the 2008 crisis, which has not been specifically researched before. While this paper uses $\operatorname{GARCH}(1,1)$ to model volatility spillover, it is important to note that multivariate $\mathrm{GARCH}$ (MGARCH) have also been broadly used to examine volatility transmission across countries or among regions. Specifically, MGARCH is especially useful to model the whole region's (such as ASEAN5) volatility co-movement. For instance, Gilenko \& Fedorova (2014) examined the mean-to-mean, volatility-to-mean and volatility-to-volatility, for external (with the rest of the world) and internal spill (within group) over effects for the stock markets of BRIC countries using MGARCH model. However we follow the route taken by Click \& Plummer (2005) by testing for cointegration to establish long run relationships. Then we proceed to test whether there exist a significant volatility spillover between the ASEAN- 5 countries and how has this changed over the three time periods - pre, during, and post the global financial crisis.

\section{Method}

\subsection{Data}

The dataset under analysis in this study is daily composite stock price indices in local currencies and US Dollars for all ASEAN- 5 countries from January 1, 1999 to February 2, 2015. The countries that will be observed are Indonesia, Malaysia, Singapore, Thailand and Philippines. These countries are the founder of ASEAN and they have similar characteristics to one another than the other ASEAN countries. Moreover, these five countries have a similar trend of FDI inflow from China, Japan, and South Korea in US Dollar terms.

We analyze the daily stock prices because it capture the market sentiment on daily basis and at the same time, reflects the market integration. These stock prices are in local currencies and US Dollar. The importance of looking at US Dollar arises from two reasons. First, investors outside ASEAN countries have to convert local ASEAN currencies returns to their home currencies, whereas using US Dollar would be convenient to them (Click \& Plummer 2005). Second, the main focus of this paper is to examine the impact of the global financial crisis that originated in the US.

The stock indices are obtained from DataStream. Table 1 lists the indices used in this study. In order to observe the effect of Global Financial Crisis, we created three periods: pre-crisis (8 August 1999 to 7 August 2007), during crisis (8 August 2007 to 31 March 2009), and post-crisis (1 April 2009 to 11 February 2015). The stock returns are computed by taking the first difference of log of stock index of each market:

$$
\Delta y_{t}=\log \frac{S_{t}}{S_{t-1}}
$$

Table 1: Country and Stock Indices in ASEAN-5

\begin{tabular}{ll}
\hline \hline Country & Stock Indices \\
\hline Indonesia & Indonesian Stock Exchange (IDX) \\
Malaysia & Kuala Lumpur Composite Index (KLCI) \\
Singapore & Straits Times Index (STI) \\
Thailand & Stock Exchange of Thailand (SET) \\
Philippine & Philippine Stock Exchange (PSEi) \\
\hline \hline
\end{tabular}




\subsection{Descriptive Statistics}

Summary statistics on the stock return and conditional variance, in local currencies and US Dollar are represented in the Appendix. There are 2071, 430, and 1531 observations in the pre-crisis, during crisis, and post-crisis period, respectively. The corresponding simple correlation tables are also presented. Among five stocks market returns, in general, compared to the pre-crisis period, we observe a higher correlation during and post crisis period for both, local currencies and US Dollar. The concern that correlations will converge to unity in the long run is our motivation for examining the long run relationship and cointegration among the ASEAN-5.

\subsection{Methodology}

\subsubsection{Cointegration}

Many financial time series appear to be integrated of order one, $I(1)$, which means it has a unit root process. Typically, if a series is $I(1)$, then a linear combination of the variables are also $I(1)$. Howbeit, if there exists a linear combination that is $I(0)$, then the series are said to be cointegrated. The series $y_{t}$ in this study refer to stocks' price (in log) $\log S_{t}$. Consider the following equations:

$$
\begin{gathered}
y_{t}=\alpha+y_{t-1}+\varepsilon_{t} \\
\Delta y_{t}=\alpha+\gamma_{t}+(\rho-1) y_{t-1}+\sum_{i=1}^{m} \theta_{i} \Delta y_{t-i}+\varepsilon_{t}
\end{gathered}
$$

or

$$
\Delta y_{t}=\alpha+\Pi_{t-1}+\Gamma \Delta y_{t-1}+{ }_{t}
$$

This is the vector error correction model (VECM) where $y_{t}$ is $\log$ (stock) at time $t ; \Delta y_{t}$ is the first difference, or the return of the stocks; $\Pi y_{t}$ is the long run matrix; $\Gamma \varepsilon_{t}$ is the error term.

Often, the controversy is on the choice of number of lags $m$. There are various model selection criteria. In this paper, AIC is chosen as the appropriate lag length tests. AIC ensures that the probability of choosing too few lags is going to zero. Testing for each country, the appropriate number of lags varies from 1 to 4 lags. Akaike Information Criterion function is:

$$
A I C=\frac{R S S}{T-k} \frac{2 k}{T-k}
$$

Subsequently, we verify whether the series and its return contain unit root using the Augmented Dickey Fuller (ADF) test:

$H_{0}: \Pi=0, y_{t}$ has a unit root, $I(1)$

$H_{1}: \Pi<0, y_{t}$ has a unit root, $I(0)$

The ADF test finding for all countries is, the stocks' price (in logs) fail to reject the $H_{0}$, which implies that all series are non-stationary. And the return of stocks' price reject the null-hypothesis, which signify stationarity, i.e. $\Delta y_{t-1}$ is $I(0)$ and thus, a cointegration test is applicable.

Consider equation (2), the rank of $\Pi$ is the number of linearly independent cointegrating vectors. We run the Johansen's method to effectively test for cointegrating vectors, i.e., testing the rank of $\Pi$

$H_{0}: \Pi=0$, no cointegration

$H_{1}: \Pi>0$, cointegration

Each of these forms a long-run equilibrium relationship between the variables. The rank of $\Pi$ in this study is found to be zero, implying there is no linear combination of which means there is not any cointegration among countries. This suggests that there is a relationship between the returns but not the stock prices in the long run.

Thereupon, we analyze the volatility co-movement between stock indices using GARCH $(1,1)$. In nature of focusing on the empirical results on volatility co-movements, the results tables for the Cointegration tests are served in the Appendix.

\subsubsection{GARCH}

According to Pederson \& Rahbek (2014), "most financial applications are, by nature, multivariate with forecasts of conditional covariance matrices as important components". While the multivariate BEKK-GARCH model by Engle \& Kroner (1995) can be used for estimating conditional covariances between ASEAN countries, it is challenging to model it in STATA. Therefore, we model a simple GARCH $(1,1)$ procedure for each time series and obtain the predicted variance of each country. Proceeding this, the variance in the GARCH $(1,1)$ of another country 

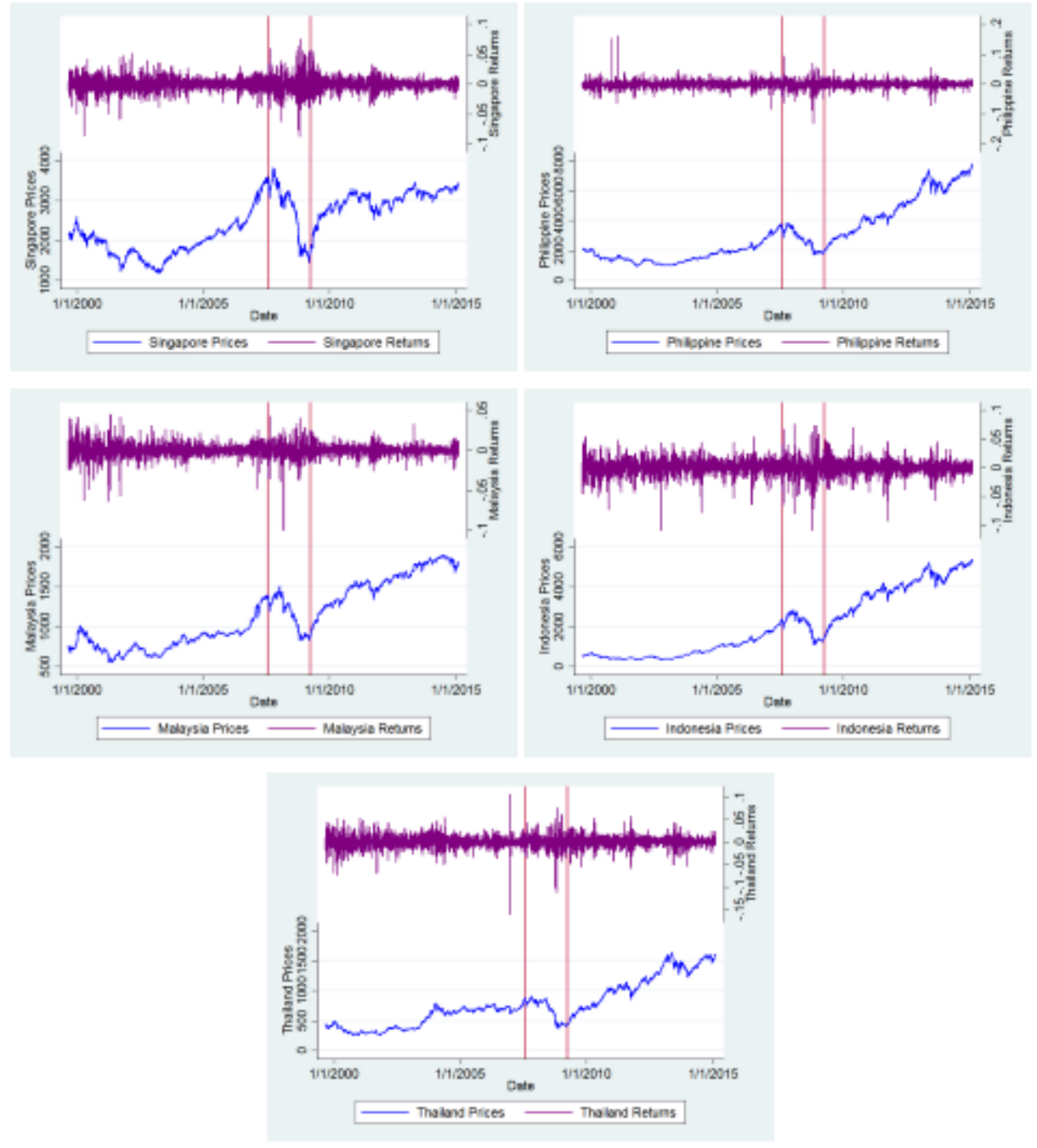

Figure 1: Stock Market Price and Return in ASEAN-5 (2000-2015) 
is used to obtain the effect of one country's volatility on another country.

Before starting with a GARCH model is the generalization of an ARCH model - Autoregressive Conditional Heteroskedasticity. For example, while applying the ARCH to a return series as below we can see that it is autoregressive in the squared returns. Further GARCH $(1,1)$ implies that it is conditional on last periods information. Lastly, the returns have non constant volatility hence heteroskedasticity.

$$
h_{t}=\alpha+\beta_{1} \varepsilon_{t-1}^{2}+\beta_{2} h_{t-1}
$$

where $h_{t}$ is the conditional covariance or volatility.

We apply the GARCH $(1,1)$ model on a single time series $t$ at once for every country. For example, Indonesian daily returns is denoted by the $i$ subscript, at time $t$.

$$
h_{i, t}=\alpha+\beta_{1} \varepsilon_{i, t-1}^{2}+\beta_{2} h_{i, t-1}
$$

As the next step we predict the conditional covariance of this time series till period $h_{t-1}$.

We then apply this predicted variance into the GARCH $(1,1)$ model of another ' $j$ ' time series.

$$
h_{j, t}=\alpha+\beta_{1} \varepsilon_{i, t-1}^{2}+\beta_{2} h_{i, t-1}+\beta_{3} h_{j, t-1}
$$

where $\beta_{1}$ is the $\mathrm{ARCH}$ coefficient, $\beta_{2}$ is the $\mathrm{GARCH}$ coefficient, and $\beta_{3}$ is the coefficient of contagion of volatility of one country to another. All coefficients are with one period lag.

\section{Results and Analysis}

This section examines the empirical characteristics of ASEAN-5 stock return volatility transmission. When countries share geographical proximity and have similar groups of investors in their markets, these markets are more than likely to influence each other. Janakiramanan \& Lamba (1998) find that, in a region, the more dominant market among the group would significantly exert its influence on docile ones.

In general, we observe the sum of $\beta_{1}$ and $\beta_{2}$ to be approximately close to 1 . This translates to volatility persistence within each countries in terms of both, local currencies and US Dollar. Table 2 provides result analysis that focuses on the $\beta_{3}$ coefficients to observe for volatility contagion. In the pre-crisis period, Indonesia and Philippines is unlikely to transmit shocks to others. It shows from the coefficients for volatility contagion with one lag are insignificant for other countries except Thailand. This may be due to the comparatively less developed financial system of the three countries. It is important to note that the $\beta_{3}$ coefficients correspond to a unit movement in the volatility. Hence, the peculiarly large results would not be observed in a real market scenario.

Since Singapore is the most advanced country in the region, one could expect significant volatility contagion from it to other countries, even before the 2007 crisis. This is supported in the result. Singapore significantly transmits volatility with one lag to Indonesia, Thailand and Philippines at $1 \%$ significance level when evaluated in US Dollar, and only to Indonesia and Philippines when using local currency. Interestingly Singapore does not significantly transmit volatility to Malaysia, yet another one of the advanced economies among the ASEAN-5. This is similar with the findings from $\mathrm{Li}$ (2007) who argues that external shock would only limitedly affect emerging financial market when their developed counterpart only weakly integrated with them.

Similar result for Malaysia since it significantly transmits volatility again at one lag to all countries (at $1 \%$ significance level) except to Singapore for both US Dollar and local currency. This is quite a peculiar observation to note that the two most developed economies of the south Asian region does not have any significant interdependence in terms of volatility. This could be expected since Malaysia introduced selective capital control from September 1998 to disentangle itself from the mess created by the repeated currency (Ringgit Malaysia) trading through the Singapore operated Central Limit Order Book which led to Ringgit's devaluation. Furthermore, when other countries were allowing their currencies to float, Malaysia pegged Ringgits to US Dollar. Thus, the significant results could be expected to be similar in terms of local currencies and US Dollar, although at different strengths. Therefore, the difference in the results in both US Dollar and local currency case can be explained using a country's exchange rate relation to the US Dollar; the more the extent of this exchange rate relation the similar would be the result.

Furthermore, the results for crisis period also of- 
fer sufficient space for interpretation of interesting results. Singapore again transmits volatility at $1 \%$ significance level to Indonesia, Thailand and Philippines when using US Dollar (Thailand becomes insignificant when examined in local currency). Malaysia, interestingly, does not transmit volatility to any other countries during the crisis period. One possible explanation for this could be Malaysia's strong 'institutional and liquidity support' that helps absorbs shocks to the economy. Thailand, on the other hand, significantly transmits volatility to Singapore, Malaysia, Indonesia and Philippines when examined using US Dollar. Indonesia too, transfers volatility to other countries except Malaysia at $1 \%$ significance level. Philippines again remain an immaterial volatility transmitter in the region except to Indonesia.

As expected, we observe quite a turnaround in the volatility contagion process between the ASEAN-5 countries after the 2007 financial crisis. The findings show that during the post-crisis (recovery) period all ASEAN countries developed together. Singapore significantly transfers volatility to all other countries including Malaysia at $1 \%$ significance level (except Philippines at $10 \%$ significance level). On contrary, Malaysia now transmits volatility to Singapore with quite high coefficient (in local currency) and to Indonesia and Thailand at $1 \%$ and $10 \%$ significance, respectively (in US Dollar). The interesting result here is that the other three countries became significant volatility transmitters. For example, when evaluating in US Dollar the volatility contagion (in one lag) from Indonesia, Thailand, and Philippines to each other is quite significant (except for Indonesia to Singapore).

In overall, the interesting result is seen in Malaysia. In pre-crisis period, it was strongly and significantly channeling stock return volatility to other countries; however, during crisis period, we observe no significant stock return volatility transmission to any country. Yet, Malaysia was able to again significantly transmit stock return volatility, and even stronger in post-crisis period, compared to pre-crisis. Another intriguing result could be the conclusion that the volatility transmission is not a two way process. For instance, observing the result for after crisis (US Dollar) we see that while Singapore transmits its volatility significantly to Indonesia, the reverse is not true.

Another interesting observation is seen with Thai- land stock market. In the pre-crisis period, Thailand was not transmitting any stock return volatility (either at 10,5 , or $1 \%$ significance level) to other countries. But during crisis, it starts to significantly transmit volatility at $1 \%$ significance level, with strongest effect given to Singapore. This trend continues in the post crisis period where Thailand transmits volatility to all other countries at $1 \%$ significance level with stronger coefficients than before (using US currency). This post crisis scenario is same for Philippines too. Collectively, this implies that these emerging markets are becoming progressively integrated with others in terms of volatility.

\subsection{Policy Implication}

The establishment of AEC in 2015 is a milestone for ASEAN regional economic integration. The observation about financial cointegration discussed in this paper is hoped to contribute to one of the many aspects of AEC. The result of our observation shows that ASEAN-5 financial system has become more integrated after the global financial crisis. Since ASEAN would establish a single market in banking system, ASEAN still have to tackle many diversity. Progressing into integrated banking market needs a strong institutional and legislation framework. While bilateral banking regulation is particularly low within the region, as suggested by Click \& Plummer (2005), ASEAN could create a supranational stock market if the capital market integration succeeds. Although it would be at a small scale, it would be a step further towards economic and financial integration.

However, it seems that financial integration within ASEAN is lagged behind the trading integration. In order to promote the integration capital market in ASEAN (which called as ASEAN Exchange), on September 2012 ASEAN establish an ASEAN Trading Link that is an arrangement to connect the cross-border trading and order routing using electronic network. The existence of ASEAN Trading Link should be utilized with broadening and deepening their linkage. This link supports the country to maintain its independence while trading. As long as the country in exchange is a member, these schemes enable stockbrokers to directly deal in the share of a country even if they do not have a trading license. For instance, an investor in Malaysia would not be charged a fee when they contact the

Economics and Finance in Indonesia Vol. 62 No. 1, April 2016, pp. 44-58 


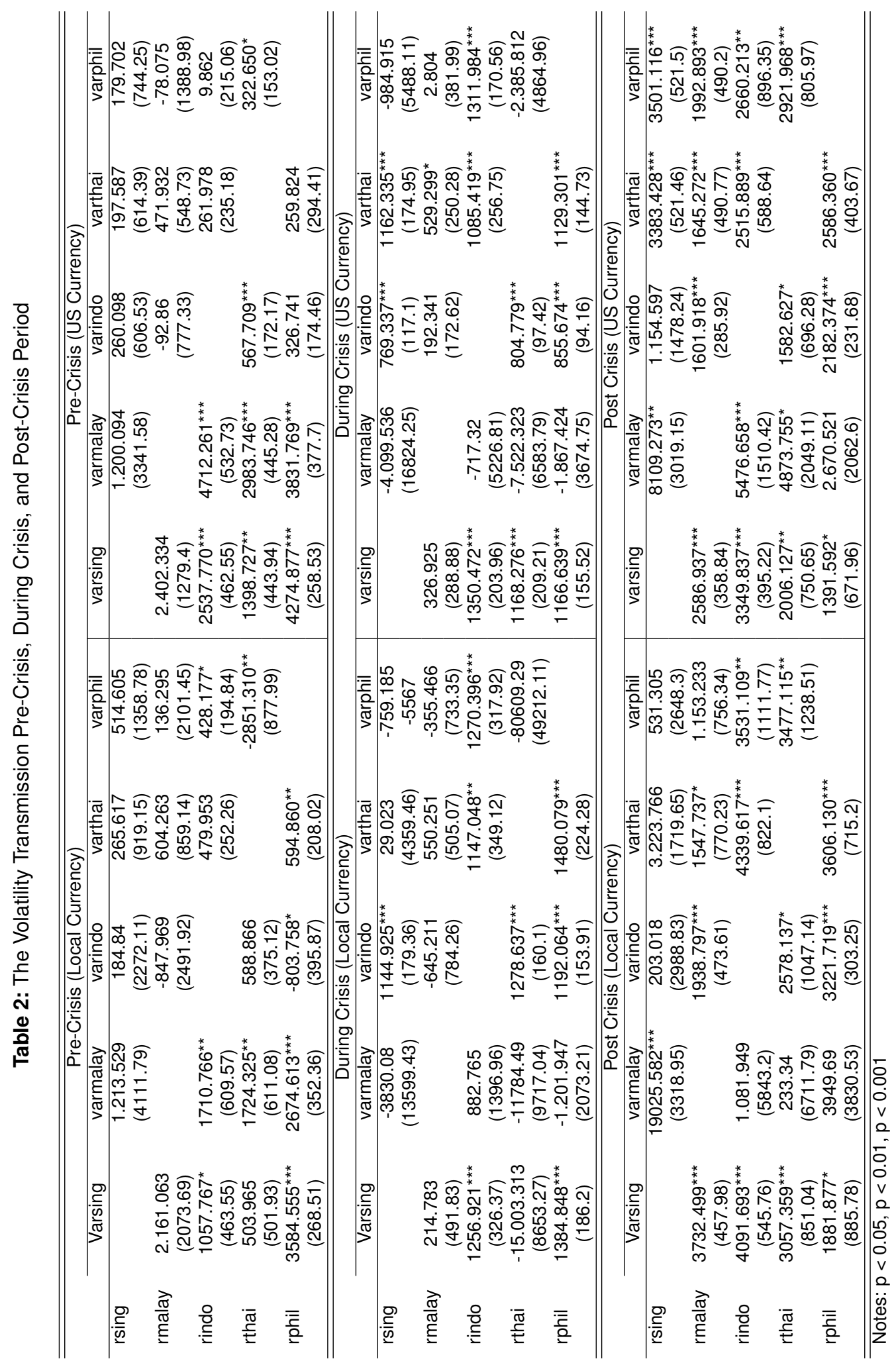


local broker of Singapore when they trade the share in the live time. However, there are some doubts about the significance of the link since it only few countries' exchange contributes to the program. In the beginning, only Singapore Exchange and Bursa Malaysia participated and followed by Thailand a few months later. Therefore, in order to maximize the benefit from financial or trading integration, the participation of all ASEAN economies are encouraged.

\section{Conclusion}

This paper investigates the financial long-term cointegration integration of the stock market of ASEAN-5 countries over the periods of January 1 , 1999 to February 2, 2015. We assess volatility comovements among ASEAN-5 stock indices using GARCH $(1,1)$ model, focusing mainly on volatility spillover between countries during the three time periods: pre, during, and post global financial crisis of 2007-2008.

The empirical findings of this paper show that the ASEAN-5 countries have indeed taken a step towards financial integration. While we do not observe any long run relationships between ASEAN-5 from Johansen's test for cointegration, we find that there has been a significant increase in the volatility spillovers between these countries especially in the recovery (post) period following the global financial crisis. Additionally, we also find evidence that more dominant market among the group would exert its influence on docile ones in the region. This is shown in the result where Singapore, being the most advanced country in the region, significantly transmits volatility to the other countries, even before (pre) the crisis period.

However, we observe a peculiar result that the two most developed markets of the South East Asia region does not have any significant interdependence in terms of volatility. Singapore does not significantly transmit volatility to Malaysia - another established market in the ASEAN-5. Whereas Malaysia does not transmit volatility to any countries during the crisis period, possibly because Malaysia's strong institutional and liquidity was able to absorb the shocks. This finding deduces an intriguing result that the volatility transmission is not a two-way process.
In conclusion, we observe quite a turnaround in the volatility spill over process between the ASEAN-5 countries in the post global financial crisis. This implies that these emerging markets are progressively integrating with each other in terms of volatility, especially after a shock. Further research could utilize MGARCH specification to be able to model the whole region's volatility co-movement as opposed to the bi-country analyses.

\section{References}

[1] Allen, DE, Amram, R \& McAleer, M 2011, 'Volatility Spillovers from The Chinese Stock Market to Economic Neighbours', (December 23, 2011). Available at SSRN 1976408.

[2] Almekinders, G, Fukuda, S, Mourmouras, A, Zhou, J, \& Zhou, YS 2015, 'ASEAN Financial Integration', IMF Working Papers 15/34, International Monetary Fund. Available from: <http://www.imf.org/external/pubs/ $\mathrm{ft} / \mathrm{wp} / 2015 / \mathrm{wp} 1534$.pdf $>$. [5 January 2016].

[3] Brooks, RD, Davidson, S \& Faff, RW 1997, 'An Examination of the Effects of Major Political Change on Stock Market Volatility: The South African Experience', Journal of Internatioal Financial Markets, Institution and Money, vol. 7, no. 3, pp. 255-275.

[4] Chakrabarti, G 2011, 'Financial Crisis and the Changing Nature of Volatility Contagion in the Asia-Pacific Region', Journal of Asset Management, vol. 12, no. 3, pp. 172-184.

[5] Click, RW \& Plummer, MG 2005, 'Stock Market Integration in ASEAN After the Asian Financial Crisis', Journal of Asian Economics, vol. 16, no. 1, pp. 5-28.

[6] Daly, KJ 2003, 'Southeast Asian Stock Market Linkages: Evidence from Pre-and Post-October 1997', ASEAN Economic Bulletin, pp. 73-85.

[7] Engle, RF \& Kroner, KF 1995, 'Multivariate Simultaneous Generalized ARCH', Econometric Theory, vol. 11, no. 01, pp. 112-150.

[8] Gilenko, E \& Fedorova, E 2014, 'Internal and External Spillover Effects for the BRIC Countries: Multivariate GARCH-in-Mean Approach', Research in International Business and Finance, vol. 31, pp. 32-45.

[9] Guidi, F \& Gupta, R 2012, 'Forecasting Volatility of the ASEAN-5 Stock Markets: A Nonlinear Approach with Non-Normal Errors', Griffith Business School Discussion Papers - Finance, No. 2012-14. Available from: <https://www.researchgate.net/ profile/Rakesh_Gupta/publication/254417848 Forecasting_volatility_of_the_ASEAN5_stock_ markets_a_nonlinear_approach_with_non-normal_ errors/links/0c96052b56158b1409000000.pdf>. [5 January 2016].

[10] Huyghebaert, N \& Wang, L 2010, 'The Co-movement of Stock Markets in East Asia: Did the 1997-1998 Asian Financial Crisis Really Strengthen Stock Market Integration?', China Economic Review, vol. 21, no. 1, pp. 98-112.

[11] Janakiramanan, S \& Lamba, AS 1998, 'An Empirical Examination of Linkages Between Pacific-Basin Stock Markets', Journal of International Financial Markets, Institution and Money, vol. 8, no. 2, pp. 155-173. 
Table 3: Summary Statistics on the Stock Returns using Local Currencies

\begin{tabular}{lrrrrr}
\hline \hline Stats & Singapore & Malaysia & Indonesia & Philippine & Thailand \\
\hline Pre-Crisis & & & & & \\
mean & 0.00019 & 0.000251 & 0.000649 & 0.000209 & 0.000297 \\
$\mathrm{~N}$ & 2070 & 2070 & 2070 & 2070 & 2070 \\
max & 0.051524 & 0.045028 & 0.053554 & 0.161776 & 0.105771 \\
min & -0.08549 & -0.06342 & -0.10934 & -0.08251 & 0.160633 \\
range & 0.137012 & 0.10845 & 0.16289 & 0.244289 & 0.266403 \\
sd & 0.011305 & 0.009119 & 0.013398 & 0.012889 & 0.014258 \\
se(mean) & 0.000249 & 0.0002 & 0.000295 & 0.000283 & 0.000313 \\
skewness & -0.44021 & -0.47399 & -0.62706 & 1.494 .529 & -0.73117 \\
kurtosis & 6.618 .294 & 9.213 .082 & 765.422 & 256.738 & 1.388 .352 \\
\hline Crisis & & & & & \\
mean & -0.0015 & -0.00091 & -0.00097 & -0.00121 & -0.00148 \\
$\mathrm{~N}$ & 430 & 430 & 430 & 430 & 430 \\
max & 0.075306 & 0.042587 & 0.076231 & 0.093653 & 0.075488 \\
min & -0.08696 & -0.09979 & -0.10954 & -0.13089 & -0.1109 \\
range & 0.162265 & 0.142372 & 0.185771 & 0.22454 & 0.18639 \\
sd & 0.020125 & 0.012181 & 0.021478 & 0.019386 & 0.018554 \\
se(mean) & 0.000971 & 0.000587 & 0.001036 & 0.000935 & 0.000895 \\
skewness & -0.01438 & -119.084 & -0.52977 & -0.6811 & -0.69629 \\
kurtosis & 5.104 .644 & 1.355 .356 & 7.524 .425 & 9.939 .566 & 9.159 .633 \\
\hline Post-Crisis & & & & & \\
mean & 0.000461 & 0.000473 & 0.000858 & 0.000884 & 0.000858 \\
$\mathrm{~N}$ & 1531 & 1531 & 1531 & 1531 & 1531 \\
max & 0.057684 & 0.033222 & 0.070136 & 0.055419 & 0.057515 \\
min & -0.03769 & -0.02531 & -0.093 & -0.06989 & -0.05812 \\
range & 0.095377 & 0.058534 & 0.163133 & 0.125304 & 0.115634 \\
sd & 0.008982 & 0.005776 & 0.011964 & 0.010782 & 0.011476 \\
se(mean) & 0.00023 & 0.000148 & 0.000306 & 0.000276 & 0.000293 \\
skewness & 0.216872 & -0.06338 & -0.41302 & -0.49699 & -0.29877 \\
kurtosis & 7.044 .606 & 5.895 .323 & 8.480 .307 & 7.119 .931 & 6.261 .934 \\
\hline \hline & & & & &
\end{tabular}

Economics and Finance in Indonesia Vol. 62 No. 1, April 2016, pp. 44-58 
Table 4: Summary Statistics for Conditional Variance using Local Currencies

\begin{tabular}{|c|c|c|c|c|c|}
\hline stats & Singapore & Malaysia & Indonesia & Philippine & Thailand \\
\hline \multicolumn{6}{|l|}{ Pre-crisis } \\
\hline mean & 0.000133 & 8.58E-05 & 0.000188 & 0.000174 & 0.000201 \\
\hline $\mathrm{N}$ & 2071 & 2071 & 2071 & 2071 & 2071 \\
\hline $\max$ & 0.000873 & 0.000618 & 0.001544 & 0.002805 & 0.003517 \\
\hline $\min$ & 2.12E-05 & 1.23E-05 & 4.94E-05 & 5.46E-05 & 7.18E-05 \\
\hline range & 0.000852 & 0.000605 & 0.001495 & 0.00275 & 0.003446 \\
\hline sd & 0.000102 & 8.47E-05 & 0.000136 & 0.000178 & 0.000196 \\
\hline se(mean) & 2.23E-06 & 1.86E-06 & $2.99 \mathrm{E}-06$ & 3.91E-06 & 4.30E-06 \\
\hline skewness & 231.664 & 2.675 .437 & 3.399 .868 & 7.758 .632 & 8.009 .741 \\
\hline kurtosis & 1.206 .276 & 1.185 .814 & 2.142 .424 & 8.394 .566 & 1.018 .596 \\
\hline \multicolumn{6}{|l|}{ Crisis } \\
\hline mean & 0.000399 & 0.000152 & 0.000428 & 0.000341 & 0.000304 \\
\hline $\mathrm{N}$ & 430 & 430 & 430 & 430 & 430 \\
\hline $\max$ & 0.002119 & 0.001098 & 0.002459 & 0.002475 & 0.002391 \\
\hline $\min$ & 7.07E-05 & 3.42E-05 & 8.46E-05 & $9.11 \mathrm{E}-05$ & 7.81E-05 \\
\hline range & 0.002049 & 0.001064 & 0.002374 & 0.002384 & 0.002312 \\
\hline sd & 0.000371 & 0.000144 & 0.000438 & 0.000342 & 0.000349 \\
\hline se(mean) & $1.79 \mathrm{E}-05$ & 6.92E-06 & 2.11E-05 & 1.65E-05 & 1.69E-05 \\
\hline skewness & 2.437 .441 & 3.400 .128 & 2.216 .819 & 3.056 .104 & 3.613 .956 \\
\hline kurtosis & 9.233 .229 & 1.811 .249 & 7.676 .319 & 1.402 .186 & 1.691 .515 \\
\hline \multicolumn{6}{|l|}{ Post-Crisis } \\
\hline mean & 9.13E-05 & 3.93E-05 & 0.000159 & 0.000137 & 0.000152 \\
\hline $\mathrm{N}$ & 1531 & 1531 & 1531 & 1531 & 1531 \\
\hline $\max$ & 0.000794 & 0.000209 & 0.001146 & 0.000897 & 0.000864 \\
\hline $\min$ & 1.68E-05 & 1.03E-05 & 4.91E-05 & 5.28E-05 & $6.55 \mathrm{E}-05$ \\
\hline range & 0.000777 & 0.000198 & 0.001096 & 0.000844 & 0.000799 \\
\hline sd & 0.000103 & 2.84E-05 & 0.000137 & 9.84E-05 & 9.52E-05 \\
\hline se(mean) & 2.63E-06 & $7.25 \mathrm{E}-07$ & 3.50E-06 & $2.51 \mathrm{E}-06$ & 2.43E-06 \\
\hline skewness & 3.307.743 & 2.122.951 & 2.962.059 & 3.638.239 & 2.690.893 \\
\hline kurtosis & 1.646 .482 & 8.331 .086 & 1.503 .659 & 2.051 .872 & 1.360 .772 \\
\hline
\end{tabular}

Table 5: Correlation Stock Returns in Local Currencies

\begin{tabular}{|c|c|c|c|c|c|}
\hline & Singapore & Malaysia & Indonesia & Philippine & Thailand \\
\hline \multicolumn{6}{|l|}{ Pre-Crisis } \\
\hline Singapore & 1 & & & & \\
\hline Malaysia & 0.375 & 1 & & & \\
\hline Indonesia & 0.3328 & 0.2564 & 1 & & \\
\hline Philippine & 0.2364 & 0.2392 & 0.2201 & 1 & \\
\hline Thailand & 0.3663 & 0.2897 & 0.261 & 0.1988 & 1 \\
\hline \multicolumn{6}{|l|}{ Crisis } \\
\hline Singapore & 1 & & & & \\
\hline Malaysia & 0.5875 & 1 & & & \\
\hline Indonesia & 0.6391 & 0.5871 & 1 & & \\
\hline Philippine & 0.4047 & 0.4776 & 0.5056 & 1 & \\
\hline Thailand & 0.6445 & 0.4979 & 0.5719 & 0.4478 & 1 \\
\hline \multicolumn{6}{|l|}{ Post-Crisis } \\
\hline Singapore & 1 & & & & \\
\hline Malaysia & 0.5223 & 1 & & & \\
\hline Indonesia & 0.5925 & 0.5091 & 1 & & \\
\hline Philippine & 0.3467 & 0.4239 & 0.4066 & 1 & \\
\hline Thailand & 0.5256 & 0.4289 & 0.5025 & 0.3393 & 1 \\
\hline
\end{tabular}

Economics and Finance in Indonesia Vol. 62 No. 1, April 2016, pp. 44-58 
Table 6: Correlation of Conditional Variance in Local Currencies

\begin{tabular}{lrrrrr}
\hline \hline & Singapore & Malaysia & Indonesia & Philippine & Thailand \\
\hline Pre-crisis & & & & & \\
Singapore & 1 & & & & \\
Malaysia & 0.6636 & 1 & & & \\
Indonesia & 0.3401 & 0.2645 & 1 & 1 & \\
Philippine & 0.2416 & 0.1824 & 0.073 & 0.1263 & 1 \\
Thailand & 0.2986 & 0.2938 & 0.2284 & & \\
\hline Crisis & & & & & \\
Singapore & 1 & & & & \\
Malaysia & 0.4156 & 1 & & & \\
Indonesia & 0.883 & 0.4969 & 1 & & \\
Philippine & 0.895 & 0.4616 & 0.8434 & & \\
Thailand & 0.9021 & 0.3427 & 0.8441 & 0.8901 & \\
\hline Post-Crisis & & & & & \\
Singapore & 1 & & & & \\
Malaysia & 0.7321 & 1 & & & \\
Indonesia & 0.5795 & 0.6623 & 1 & & \\
Philippine & 0.3418 & 0.4465 & 0.7053 & & \\
Thailand & 0.453 & 0.5245 & 0.7398 & 0.6654 & \\
\hline \hline
\end{tabular}

Table 7: Summary Statistics on the Stock Return using US Dollar

\begin{tabular}{lrrrrr}
\hline \hline stats & Singapore & Malaysia & Indonesia & Philippine & Thailand \\
\hline Pre-Crisis & & & & & \\
mean & 0.000241 & 0.000295 & 0.000554 & 0.000143 & 0.000357 \\
$\mathrm{~N}$ & 2070 & 2070 & 2070 & 2070 & 2070 \\
max & 0.05414 & 0.045 & 0.119189 & 0.212658 & 0.096726 \\
min & -0.08538 & -0.06349 & -0.15415 & -0.08587 & -0.16064 \\
range & 0.139518 & 0.108486 & 0.273339 & 0.298526 & 0.257367 \\
sd & 0.011745 & 0.009343 & 0.018811 & 0.014461 & 0.015532 \\
se(mean) & 0.000258 & 0.000205 & 0.000414 & 0.000318 & 0.000341 \\
skewness & -0.44689 & -0.47802 & -0.43487 & 2.133 .717 & -0.66373 \\
kurtosis & 6.177 .422 & 8.744 .907 & 9.544 .923 & 3.556 .102 & 1.103 .817 \\
\hline Crisis & & & & & \\
mean & -0.00151 & -0.00103 & -0.00147 & -0.00136 & -0.00158 \\
$\mathrm{~N}$ & 430 & 430 & 430 & 430 & 430 \\
max & 0.091684 & 0.050286 & 0.128618 & 0.093331 & 0.078487 \\
min & -0.08673 & -0.11014 & -0.13815 & -0.1391 & -0.11599 \\
range & 0.178411 & 0.16043 & 0.266768 & 0.232427 & 0.194474 \\
sd & 0.021948 & 0.014205 & 0.02527 & 0.021703 & 0.019272 \\
se(mean) & 0.001058 & 0.000685 & 0.001219 & 0.001047 & 0.000929 \\
skewness & -0.09175 & -0.91177 & -0.4542 & -0.64869 & -0.71059 \\
kurtosis & 5.171 .745 & 1.139 .861 & 9.064 .784 & 8.357 .797 & 8.910 .587 \\
\hline Post-Crisis & & & & & \\
mean & 0.000533 & 0.000481 & 0.000797 & 0.000941 & 0.000912 \\
$\mathrm{~N}$ & 1531 & 1531 & 1531 & 1531 & 1531 \\
max & 0.072198 & 0.052187 & 0.074662 & 0.056224 & 0.061029 \\
min & -0.04724 & -0.03863 & -0.08244 & -0.07305 & -0.06596 \\
range & 0.119434 & 0.090819 & 0.157105 & 0.129273 & 0.126987 \\
sd & 0.010749 & 0.008483 & 0.014133 & 0.012231 & 0.012882 \\
se(mean) & 0.000275 & 0.000217 & 0.000361 & 0.000313 & 0.000329 \\
skewness & 0.179491 & 0.069006 & -0.15488 & -0.45269 & -0.25105 \\
kurtosis & 6.994 .017 & 5.850 .875 & 7.228 .965 & 6.300 .402 & 6.148 .867 \\
\hline \hline & & & & &
\end{tabular}

Economics and Finance in Indonesia Vol. 62 No. 1, April 2016, pp. 44-58 
Table 8: Summary Statistics for Conditional Variance using US Dollar

\begin{tabular}{lrrrrr}
\hline \hline stats & Singapore & Malaysia & Indonesia & Philippine & Thailand \\
\hline Pre-Crisis & & & & & \\
mean & 0.000144 & $9.12 \mathrm{E}-05$ & 0.000373 & 0.000224 & 0.000254 \\
$\mathrm{~N}$ & 2071 & 2071 & 2071 & 2071 & 2071 \\
max & 0.000855 & 0.000591 & 0.002781 & 0.004534 & 0.00486 \\
min & 0.000026 & $2.04 \mathrm{E}-05$ & $6.51 \mathrm{E}-05$ & $6.04 \mathrm{E}-05$ & $6.23 \mathrm{E}-05$ \\
range & 0.000829 & 0.00057 & 0.002716 & 0.004474 & 0.004798 \\
sd & 0.000102 & $7.93 \mathrm{E}-05$ & 0.000327 & 0.000312 & 0.000272 \\
se(mean) & $2.24 \mathrm{E}-06$ & $1.74 \mathrm{E}-06$ & $7.19 \mathrm{E}-06$ & $6.86 \mathrm{E}-06$ & $5.98 \mathrm{E}-06$ \\
skewness & 2.042 .935 & 2.722 .465 & 2.893 .746 & 8.452 .068 & 7.607 .562 \\
kurtosis & 1.001 .884 & 122.254 & 1.447 .063 & 9.040 .708 & 9.825 .067 \\
\hline Crisis & & & & & \\
mean & 0.000469 & 0.000196 & 0.000648 & 0.000456 & 0.000369 \\
$\mathrm{~N}$ & 430 & 430 & 430 & 430 & \\
max & 0.002566 & 0.001262 & 0.003977 & 0.003052 & 0.00345 \\
min & 0.000084 & $6.05 \mathrm{E}-05$ & $9.62 \mathrm{E}-05$ & 0.000108 & 0.000064 \\
range & 0.002482 & 0.001201 & 0.003881 & 0.002944 & 0.003386 \\
sd & 0.000452 & 0.000162 & 0.000687 & 0.000434 & 0.000472 \\
se(mean) & $2.18 \mathrm{E}-05$ & $7.79 \mathrm{E}-06$ & $3.31 \mathrm{E}-05$ & $2.09 \mathrm{E}-05$ & $2.28 \mathrm{E}-05$ \\
skewness & 2.519 .842 & 3.232 .777 & 2.215 .142 & 2.838 .779 & 3.852 .567 \\
kurtosis & 9.452 .877 & 1.669 .942 & 7.998 .496 & 12.465 & 1.915 .631 \\
\hline Post-Crisis & & & & & \\
mean & 0.000128 & $7.87 \mathrm{E}-05$ & 0.000231 & 0.000174 & 0.000191 \\
$\mathrm{~N}$ & 1531 & 1531 & 1531 & 1531 & 1531 \\
max & 0.001029 & 0.000364 & 0.001553 & 0.00101 & 0.001456 \\
min & $2.09 \mathrm{E}-05$ & $2.27 \mathrm{E}-05$ & $5.84 \mathrm{E}-05$ & $5.55 \mathrm{E}-05$ & $5.93 \mathrm{E}-05$ \\
range & 0.001008 & 0.000342 & 0.001494 & 0.000954 & 0.001396 \\
sd & 0.000137 & $5.36 \mathrm{E}-05$ & 0.000199 & 0.000124 & 0.00015 \\
se(mean) & $3.50 \mathrm{E}-06$ & $1.37 \mathrm{E}-06$ & $5.08 \mathrm{E}-06$ & $3.16 \mathrm{E}-06$ & $3.82 \mathrm{E}-06$ \\
skewness & 2.756 .213 & 1.960 .697 & 2.610 .598 & 3.026 .691 & 3.099 .877 \\
\hline \hline & & & & &
\end{tabular}

Table 9: Correlation of Stock Return in US Dollar

\begin{tabular}{|c|c|c|c|c|c|}
\hline & Singapore & Malaysia & Indonesia & Philippine & Thailand \\
\hline \multicolumn{6}{|l|}{ Pre-Crisis } \\
\hline Singapore & 1 & & & & \\
\hline Malaysia & 0.3963 & 1 & & & \\
\hline Indonesia & 0.315 & 0.248 & 1 & & \\
\hline Philippine & 0.2616 & 0.2619 & 0.1993 & 1 & \\
\hline Thailand & 0.3914 & 0.2968 & 0.2725 & 0.2212 & 1 \\
\hline \multicolumn{6}{|l|}{ Crisis } \\
\hline Singapore & 1 & & & & \\
\hline Malaysia & 0.647 & 1 & & & \\
\hline Indonesia & 0.6637 & 0.5946 & 1 & & \\
\hline Philippine & 0.4805 & 0.5272 & 0.5881 & 1 & \\
\hline Thailand & 0.6546 & 0.5272 & 0.6255 & 0.4805 & 1 \\
\hline \multicolumn{6}{|l|}{ Post-Crisis } \\
\hline Singapore & 1 & & & & \\
\hline Malaysia & 0.6428 & 1 & & & \\
\hline Indonesia & 0.6202 & 0.6123 & 1 & & \\
\hline Philippine & 0.42 & 0.504 & 0.4835 & 1 & \\
\hline Thailand & 0.5617 & 0.5309 & 0.5253 & 0.4156 & 1 \\
\hline
\end{tabular}

Economics and Finance in Indonesia Vol. 62 No. 1, April 2016, pp. 44-58 
Table 10: Correlation of Conditional Variance in US Dollar

\begin{tabular}{|c|c|c|c|c|c|}
\hline & Singapore & Malaysia & Indonesia & Philippine & Thailand \\
\hline \multicolumn{6}{|l|}{ Pre-Crisis } \\
\hline Singapore & 1 & & & & \\
\hline Malaysia & 0.657 & 1 & & & \\
\hline Indonesia & 0.3778 & 0.3622 & 1 & & \\
\hline Philippine & 0.2024 & 0.1548 & 0.0479 & 1 & \\
\hline Thailand & 0.2916 & 0.3229 & 0.207 & 0.1039 & 1 \\
\hline \multicolumn{6}{|l|}{ Crisis } \\
\hline Singapore & 1 & & & & \\
\hline Malaysia & 0.4413 & 1 & & & \\
\hline Indonesia & 0.9112 & 0.5183 & 1 & & \\
\hline Philippine & 0.9061 & 0.5118 & 0.8902 & 1 & \\
\hline Thailand & 0.877 & 0.3752 & 0.84 & 0.8749 & 1 \\
\hline \multicolumn{6}{|l|}{ Post-Crisis } \\
\hline Singapore & 1 & & & & \\
\hline Malaysia & 0.7649 & 1 & & & \\
\hline Indonesia & 0.7369 & 0.7547 & 1 & & \\
\hline Philippine & 0.4272 & 0.5031 & 0.7119 & 1 & \\
\hline Thailand & 0.4917 & 0.5146 & 0.7202 & 0.6863 & 1 \\
\hline
\end{tabular}

[12] Li, H 2007, 'International Linkages of the Chinese Stock Exchanges: A Multivariate GARCH Analysis', Applied Financial Economics, vol. 17, no. 4, pp. 285=-297.

[13] Li, Y \& Giles, DE 2013, 'Modelling Volatility Spillover Effects Between Developed Stock Markets and Asian Emerging Stock Markets', Econometrics Working Paper EWP1301, Department of Economics University of Victoria. Available from: <https://www.uvic.ca/socialsciences/ economics/assets/docs/econometrics/ewp1301.pdf >. [5 January 2016].

[14] Morana, C \& Beltratti, A 2008, 'Comovements in International Stock Markets', Journal of International Financial Markets Institutions and Money, vol. 18, no. 1, pp. 31-45.

[15] Narayan, S, Sriananthakumar, S \& Islam, SZ 2014, 'Stock Market Integration of Emerging Asian Economies: Pattern and Causes', Economic Modelling, vol. 39, pp. 19-31.

[16] Pedersen, RS \& Rahbek, A 2014, 'Multivariate Variance Targeting in the BEKK-GARCH Model', The Econometrics Journal, 17, no. 1, pp. 24-55.

[17] Samkharadze, B 2009, 'Volatility Spillovers in European Stock Markets: A multivariate GARCH Analysis', Mimeo, Graduate School of Economics, Université Catholique de Louvain, Belgium.

[18] Wang, L 2014, 'Who Moves East Asian Stock Markets? The Role of the 2007-2009 Global Financial Crisis', Journal of International Financial Markets, Institutions and Money, vol. 28, pp.182-203. 